\title{
Root and Crown Rot Fungi Associated with Spring, Facultative, and Winter Wheat in Turkey
}

Berna Tunali, Department of Plant Protection, Agricultural Faculty, Ondokuz Mayıs University, Kurupelit, Samsun 55139 Turkey; Julie M. Nicol and David Hodson, International Maize and Wheat Improvement Center, PK 39 Emek, Ankara, Turkey and Apdo. 6-641, 06600 Mexico DF Mexico; Zafer Uçkun, Horticulture Research Institute, Yalova İstanbul, Turkey; Orhan Büyük and Durmuş Erdurmuş, Plant Protection Central Research Institute, Bağdat Str. No. 250 Yenimahalle, Ankara 06170 Turkey; Hakan Hekimhan, Agricultural Research Institute, Edirne, Turkey; Hüseyin Aktaş, Plant Protection Department, Forestry Faculty, University of Ankara, Çankırı; M. Aydin Akbudak and S. Ahmet Bağcı, Bahri Dagdas International Agricultural Research Institute, Konya, Turkey

\begin{abstract}
Tunali, B., Nicol, J. M., Hodson, D., Uçkun, Z., Büyük, O., Erdurmuş, D., Hekimhan, H., Aktaş, H., Akbudak, M. A., and Bağc1, S. A. 2008. Root and crown rot fungi associated with spring, facultative, and winter wheat in Turkey. Plant Dis. 92:1299-1306.

The objective of this study was to determine the distribution frequency of the fungi associated with wheat (Triticum aestivum) crowns and roots in cereal producing areas of Turkey through a targeted survey of 518 commercial fields over a 2-year period. More than $26 \%$ of the fields had one or more of the fungal species commonly reported as part of the dryland root rot complex, Fusarium culmorum (14\%) > Bipolaris sorokiniana $(10 \%)>$ F. pseudograminearum $(2 \%)$. The fungi considered to be part of the high rainfall root rot complex were found at very low frequencies: $2 \%$ for Gaeumannomyces graminis and 3\% for Pythium spp. Species of Rhizoctonia were found in $22 \%$ of the fields. Several Fusarium species considered to be less or nonpathogenic to cereals were also found in high frequencies at $11 \%$ (F. oxysporum, F. chlamydosporum), $10 \%(F$. sporotrichioides), and $8 \%$ (F. avenaceum and $F$. solani). The mostly random distribution of cereal root-rotting species across the survey area suggests the fungi are not distributed in any distinct agroecological relationship. As a result, the relative economic importance of a given species on wheat will be determined by a number of factors, such as their fungal pathogenicity, host susceptibility/tolerance, and the seasonal conditions. Results from this study suggest that there are a wide range of fungal species associated with root and crown tissues of wheat.
\end{abstract}

Turkey is among the 10 largest wheat (Triticum aestivum L.) producers worldwide with annual production varying between 16 and 21 million tonnes, including 4 to 6 million tonnes of durum wheat (Triticum durum L.). Turkey's climate is extremely diverse (10). Southern and western coastal regions have Mediterranean, hot and dry summers with mild, rainy winters. The northern coast is a high rainfall region. Central Anatolia has continental, dry, hot summers and cold, low rainfall and low humidity winters. Eastern Anatolia has extremely cold winters. The European part of Marmara region has moderately cold winters and humid summers. National average grain yield is approximately $2 \mathrm{t} \mathrm{ha}^{-1}$ from the total wheat production area of $9.5 \mathrm{Mha}$; however, due to diverse agroecological conditions it varies greatly from $1 \mathrm{t} \mathrm{ha}^{-1}$ in the eastern region

Corresponding author: B. Tunali

E-mail: btunali@omu.edu.tr

Accepted for publication 2 May 2008.

doi:10.1094/PDIS-92-9-1299

(c) 2008 The American Phytopathological Society predominate. Invasion of crown and root tissues by root and crown rotting fungi diminishes the plant's capacity for efficient nutrient and water uptake. Damage caused by these pathogens is difficult to assess from year to year due to differences in location, crop management, and climatic factors. Recognition of the role of soilborne pathogens as a limiting factor for wheat production potential in most areas is problematic due to a focus on more visible foliar and head diseases. Identification and quantification of root diseases involves more laborious procedures than the simple visual observations needed to detect and quantify the presence of foliar and head pathogens $(43,51)$. In addition, there are usually many species of root rotting fungi associated with root disease and yield loss; however, their economic importance is predominately determined by plant tolerance and the associated environmental conditions.

The dryland root rot complex (DLRRC) is known by a variety of names including dryland foot rot, Fusarium foot rot, crown rot, dryland root rot, and common root rot (41). Pathogens associated with the complex include Bipolaris sorokiniana (Sacc.) Shoemaker $($ Syn. $=$ Helminthosporium sativum, $H$. sorokinianum, teleomorph Cochliobolus sativus ((Ito \& Kurib.) Drech. ex Dast.), Microdochium nivale (Fr.:Fr.) Samuels \& I.C. Hallett (=Fusarium nivale (Fr.) Sorauer), and several Fusarium spp. The two most frequently reported Fusarium species are F. pseudograminearum O'Donnell \& Aoki (formerly F. graminearum Group 1, teleomorph Gibberella coronicola) and F. culmorum W.G. Smith, while several others such as $F$. acuminatum, F. avenaceum, $F$. oxysporum, and $F$. crookwellense have also been reported $(12,25,47)$. Fusarium spp. are a diverse group of fungi which damage small-grain cereals by rotting the seed, seedlings, roots, crowns, basal stems, and in some cases, infect the heads or spikes (41). Damage to spring and winter cereals often goes unnoticed until prematurely ripening heads (whiteheads) appear shortly before the crops mature (41). B. sorokiniana causes a soilborne disease of 
seedlings similar to that of Fusarium spp., and in particular causes browning of the subcrown internode. However it is not associated with the "white-head" or premature death of wheat tillers. Microdochium nivale is an important pathogen in cool temperate zones and causes snow mold of winter cereals. It also causes seedling infection and foot rot during cool temperatures. In the cooler areas of the subtropics, this organism causes leaf blotches on wheat, triticale, and rye (54). These different species may occur singly, but they often coexist in the same fields and even within individual plants (47).

Once plants are infected, the root rotting complex is most damaging under moisture-restricted conditions $(6,12,16,40-42)$.
Although many species are associated with the DLRRC, $F$. pseudograminearum, $F$. culmorum, and $B$. sorokiniana are the most pathogenic and economically important pathogens $(12,41,46)$. In the Pacific Northwest of the United States, this complex causes latent infections with the measurable effects on yield becoming most apparent when the cereals are subjected to

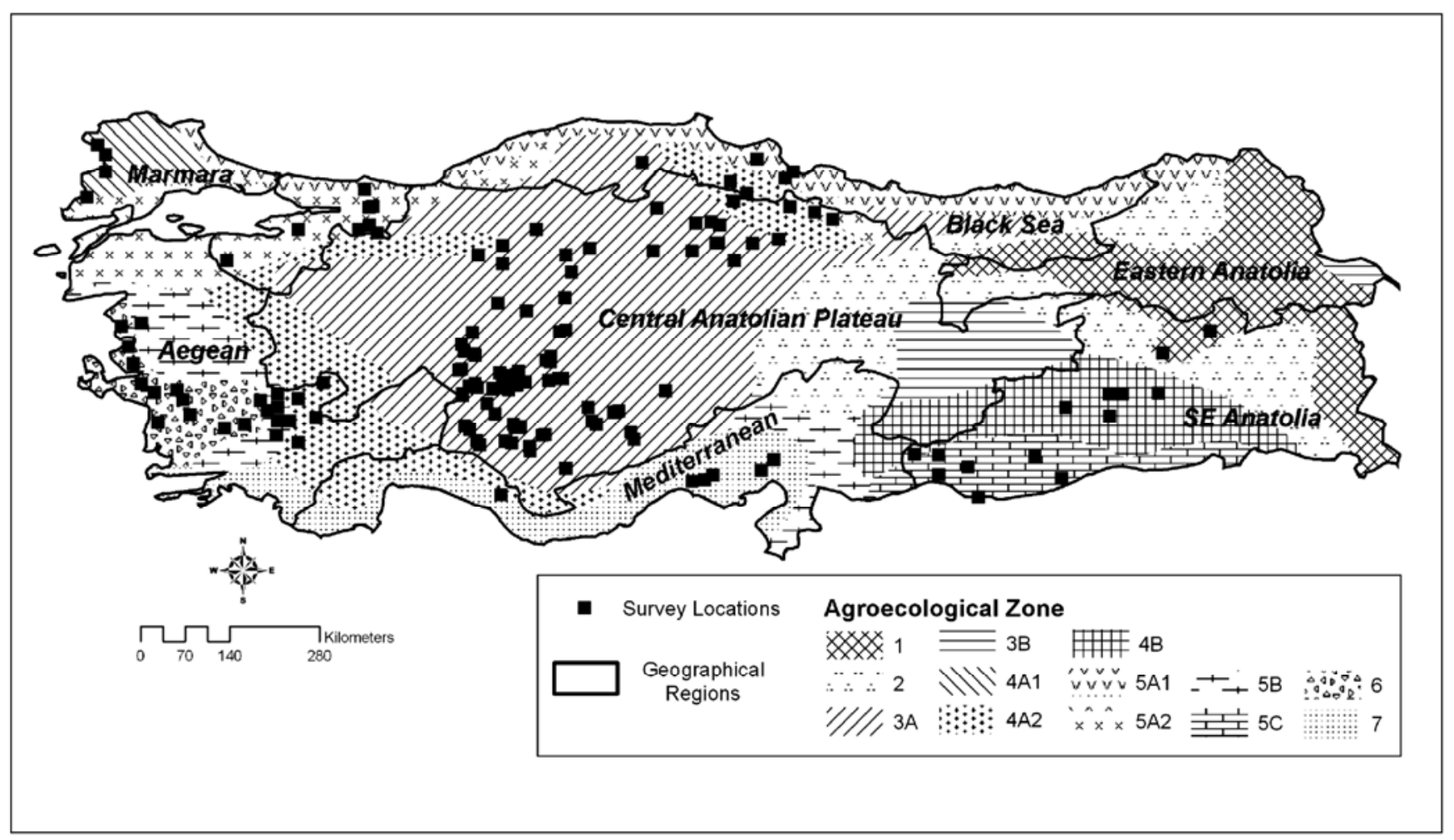

Fig. 1. Survey sites across geographical regions and agroecological wheat field growing zones of Turkey where wheat fields were sampled in 2001 and 2003. Most sites included more than one field. Geographical regions and agroecological zones were described by Braun et al. (10) and Guler et al. (27), respectively.

Table 1. Agroecological zone and geographical regions of wheat production in Turkey with respect to climate, production area, yield, and wheat growth habit as reported by Guler et al. (27) and Braun et al. (10)

\begin{tabular}{|c|c|c|c|c|c|c|c|c|c|c|}
\hline Agroecological zone $^{\mathbf{a}}$ & $\begin{array}{l}\text { Wheat } \\
\text { growth } \\
\text { habit }^{\text {b }}\end{array}$ & $\begin{array}{c}\text { Rainfall } \\
2000 \\
(\mathbf{m m})\end{array}$ & $\begin{array}{c}\text { Rainfall } \\
2001 \\
(\mathbf{m m})\end{array}$ & $\begin{array}{c}\text { Annual } \\
\text { rainfall }(\mathbf{m m}) \\
(\mathbf{1 9 9 4 - 9 8 )}\end{array}$ & $\begin{array}{c}\text { Mean } \\
\text { temp }\left({ }^{\circ} \mathrm{C}\right) \\
2000\end{array}$ & $\begin{array}{c}\text { Mean } \\
\text { temp }\left({ }^{\circ} \mathrm{C}\right) \\
2001\end{array}$ & $\begin{array}{c}\text { Mean temp } \\
\left({ }^{\circ} \mathrm{C}\right) \\
1994-98\end{array}$ & $\begin{array}{c}\text { Area } \\
\text { (ha) }\end{array}$ & $\begin{array}{c}\text { Ave yld } \\
\text { (t/ha) }\end{array}$ & $\begin{array}{c}\text { National } \\
\text { production } \\
(\%)\end{array}$ \\
\hline 1 & $\mathrm{~W}$ & & & 700 & & & 8 & 536 & 1.13 & 3 \\
\hline 2 & W & & & 435 & & & 8 & 715 & 1.53 & 6 \\
\hline $3 \mathrm{~A}$ & $\mathrm{~W}, \mathrm{~F}$ & & & 350 & & & 11 & 3,650 & 1.85 & 38 \\
\hline $3 B$ & $\mathrm{~W}, \mathrm{~F}$ & & & 380 & & & 13 & 249 & 1.46 & 2 \\
\hline 4A1 & $\mathrm{W}, \mathrm{F}$ & & & 480 & & & 14 & 402 & 3.06 & 7 \\
\hline $4 \mathrm{~A} 2$ & $\mathrm{~F}$ & & & 490 & & & 14 & 582 & 1.40 & 5 \\
\hline $4 B$ & $\mathrm{~F}$ & & & 320 & & & 22 & 678 & 1.50 & 6 \\
\hline $5 \mathrm{~A} 1$ & $\mathrm{~S}$ & & & 745 & & & 17 & 303 & 2.30 & 4 \\
\hline $5 \mathrm{~A} 2$ & $\mathrm{~S}, \mathrm{~F}$ & & & 700 & & & 15 & 638 & 2.70 & 10 \\
\hline $5 \mathrm{~B}$ & $\mathrm{~S}, \mathrm{~F}$ & & & 750 & & & 15 & 486 & 2.32 & 6 \\
\hline $5 \mathrm{C}$ & S & & & 420 & & & 18 & 403 & 1.75 & 4 \\
\hline 6 & $\mathrm{~S}$ & & & 799 & & & 18 & 109 & 3.04 & 2 \\
\hline 7 & $S$ & & & 540 & & & 19 & 566 & 2.66 & 8 \\
\hline \multicolumn{11}{|l|}{ Geographical region $^{\mathrm{c}}$} \\
\hline Cent. Anatolian Plateau & W & 330 & 362 & 358 & 11 & 13 & 12 & & & \\
\hline Aegean & $\mathrm{S}$ & 670 & 682 & 616 & 17 & 18 & 17 & & & \\
\hline Marmara & $S$ & 695 & 727 & 752 & 15 & 15 & 14 & & & \\
\hline South East Anatolia & $\mathrm{S}, \mathrm{F}$ & 516 & 550 & 536 & 17 & 17 & 17 & & & \\
\hline Black Sea & $S$ & 520 & 432 & 548 & 13 & 15 & 14 & & & \\
\hline
\end{tabular}

${ }^{a}$ Agroecological zone. After Guler et al. (27) given in Figure 1.

${ }^{\mathrm{b}}$ Winter (W), facultative (F), spring (S).

${ }^{\mathrm{c}}$ Geographical region as illustrated in Figure 1. 
water stress later in the growing season and the temperatures are high (41). Burgess et al. (12) reviewed crown rot and noted that infection by F. pseudograminearum only occurs in relatively moist soils with optimum water potential of -0.3 to $-0.6 \mathrm{MPa}$.

These dryland root rots have been found in most parts of the world, and especially under drought stress, they have caused yield loss exceeding 50\% $(35,37,41)$. Crown rot caused by Fusarium spp. is of economic importance in Australia, Europe, North America, South America, West Asia, North Africa, and South Africa (14). Recently, losses of up to $43 \%$ on common bread wheat cultivars have been reported from the Central Anatolian Plateau of Turkey (29), with additional detrimental effects on grain quality $(2,4)$.

Rhizoctonia spp. are also a commonly reported cause of damaged cereal root and crown tissue. Rhizoctonia root rot and bare patch are caused by Rhizoctonia solani Kühn AG-8, which causes lesions and pruning of seminal and crown roots, particularly in rained cereal production systems in Australia and the U.S. Pacific Northwest (41). Rhizoctonia oryzae Ryker $\&$ Gooch also causes root rot in the Pacific Northwest (41). Sharp eyespot, caused by Rhizoctonia cerealis E.P. Hoeven (teleomorph Ceratobasidium cereale D. Murray \& L.L. Burpee), causes lesions on lower tillers resulting in premature death of tillers and whitehead formation. Sharp eyespot is found particularly in temperate regions of the world including The Netherlands, Germany, South Africa, China (28), United Kingdom (15), and New Zealand (20). This disease has caused losses of up to $18 \%$ on winter cereals in New Zealand (20) and 26\% in England and Wales (15). $R$. cerealis has also been reported to be widespread in Turkey and is a potentially economically important crown pathogen of wheat $(4,5)$.

To date in Turkey three smaller regional surveys $(3,4,33)$ have also implicated $F$. culmorum, B. sorokiniana, and Rhizoctonia spp. as the main causal agents of dryland root rot on wheat.

The high rainfall root rot complex (HRRRC) is associated with several species of fungi, including Gaeumannomyces graminis (Sacc.) Arx \& Olivier var. tritici Walker, the cause of take-all disease, and various species of Pythium which have been reported to cause losses under wetter soil conditions. Take-all is most damaging under wet conditions where it causes patches of stunted, prematurely blighted plants often with black mycelial growth on and within the roots, crown, and tiller bases $(41,50)$. Take-all appears to be under-recognized in low-rainfall dryland environments such as the U.S. Pacific Northwest (41), where the fungus infects individual plants instead of plants in patches, and growth of the fungus from roots upward usually stops in the crown rather than moving upward onto tiller bases.

Pythium spp. infect germinating seeds and root tips, resulting in the stripping of fine rootlets and root hairs of plants (41). Cook and Veseth (19) have referred to Pythium as the "common cold", with its highest frequency and severity being found in high-rainfall areas with cool, wet soils covered with crop debris (17). Pythium root rot has been reported as a yieldlimiting disease on wheat and barley produced in North America, Australia, and the United Kingdom $(9,18,39,41,50)$.

The survey described in this paper was conducted throughout the main cereal growing regions of Turkey with the objective of determining the distribution frequency of root and crown rotting fungi. The distribution of these pathogens was assessed in relation to agroecological factors associated with wheat production in different parts of the country.

\section{MATERIALS AND METHODS}

Ecological and regional zones for survey areas and sampling. The study was carried out in six representative wheat growing regions of Turkey including the Central Anatolia Plateau, Marmara, Aegean, Black Sea, Mediterranean, and South East Anatolia agroecological wheat zones defined by Guler et al. (27; Fig. 1 and Table 1). Bread and durum wheat samples were collected near plant maturity (growth stage 92 of the Zadoks scale) during June and July in 2000 and 2001 (53). Fields were selected at random based on an approximate separation distance of $20 \mathrm{~km}$, field size of approximately 10 ha, the maturity of wheat plants, and field accessibility. At each site, five sampling points were made in a zig zag pattern (36), with each point being $20 \mathrm{~m}$ apart. At each of the five points, approximately 20 plants were collected, and on return to the laboratory 12 main stems with intact crown and subcrown tissue were randomly selected from each transect point, making a total of 60 main stems per site. The plants and roots collected at each site were stored in paper bags at $4^{\circ} \mathrm{C}$ until fungal isolation was performed.

A differing geographical focus of sampling occurred during the two survey years. In 2000, the lower elevation and wetter environments of the Aegean and Marmara regions were sampled, and all other regions were sampled in 2001.

Isolation and identification of fungi. The 60 selected stems from each field were washed thoroughly under running water. Two diseased $2-\mathrm{cm}$ crown sections and one diseased 2-cm root section were taken from each stem (180 sections per survey site). These sections were surfacesterilized with $1 \% \mathrm{wt} / \mathrm{vol}$ sodium hypochlorite for $3 \mathrm{~min}$, rinsed three times in sterile distilled water, and dried on sterile filter paper. Sections were plated onto fullstrength potato dextrose agar (PDA) medium. The plates were incubated at $24 \pm$ $1{ }^{\circ} \mathrm{C}$ for 4 to 5 days under a 12 -h photoperiod. Isolates were then transferred to fullstrength PDA tubes for further identification.

The isolates resembling Fusarium species were subcultured onto synthetic nutrient agar (SNA) and carnation leaf agar (CLA) for sporulation and identification. All plates were incubated under a combination of white fluorescent and black lights with a 12 -h photoperiod at $23 \pm 1^{\circ} \mathrm{C}$ for at least 7 days. Identification of Fusarium species was based on macro and micro conidial morphology, phialid structure, and hyphal characteristics observed under a compound microscope at $\times 200$ to $\times 400$ magnification $(9,13,23,26,44)$. Other fungi were identified using keys based on hyphal and conidial morphologies $(7,24)$.

Data were recorded based on the presence or absence of different fungal species in a field. If a particular fungus was isolated from one or more of the 180 plated plant sections from a given field, then the fungus was considered present. These were then collated for a particular agroecological region or geographic zone (Fig. 1) and expressed as percent frequency based on the number of fields sampled in that region or zone.

Environmental characterization. All fields were geo-referenced and incorporated into a geographical information systems (GIS) framework (Environmental Systems Research Institute, Inc. (ESRI), Redlands, CA; ArcGIS v 9.1). In cases where no precise GPS location data existed, geographical place names recorded in the survey were matched to existing spatial databases of populated places in Turkey. For each survey location, climate (long-term normal precipitation, i.e., monthly averages for the period 1950 to 2000) and elevation data were extracted from the WorldCLIM database (30) using standard point intersect tools within the GIS. The spatial resolution of the WorldCLIM data was 30 arc seconds (approximately $1 \mathrm{~km}^{2}$ grid cell sizes). All environmental data were analyzed on either an individual species basis or as a group of species according to their environmental association including DLRRC and HRRRC.

Data analysis. For the extracted environmental variables, standard parametric statistical tests (chi-square, $t$ test, and ANOVA) were used to determine if significant differences existed between means for individual species or groups of species. Proportions of species associated with specific regions or agro-zones were analyzed in the same manner.

In order to determine any significant spatial distribution patterns for the different fungal species, geospatial statistics were used. All fields (with or without 
fungi) were included in the analysis, and tests for spatial autocorrelation were undertaken using Moran's I statistic (49). This statistic provides an evaluation of whether the observed distribution pattern for an exhibited fungal species is clustered, dispersed, or random. All tests were implemented within the spatial statistics component of ArcGIS (ESRI). In this analysis, inverse distance was used as the conceptualization of spatial relationships and Euclidean distances with no threshold limit.

For analytical purposes, the root and crown rotting fungi were divided into two groups based on the literature describing the main cereal pathogens and their damage associated with the low or high-rainfall environments. The groupings considered were the DLRRC, including the most reported causal agents $B$. sorokiniana, $F$. culmorum, and $F$. pseudograminearum, and the HRRRC, including G. graminis var. tritici and Pythium spp. All other species of root and crown rotting fungi were placed in the category of other root and crown fungi.

\section{RESULTS}

DLRRC. More than $26 \%$ of fields had one or more of the common DLRRC species isolated from crown and root tissue of wheat. Considering individual species, $14 \%$ of fields had $F$. culmorum, $10 \% \mathrm{~B}$. sorokiniana, and $2 \% \mathrm{~F}$. pseudograminearum (Table 2). A widespread distribution of DLRRC species was documented throughout Turkey, with at least one of the three key DLRRC species being found in each of the six geographical regions included in the survey. Similarly, at least one DLRRC species was detected in all of the wheat agroecological zones (Table 2). No significant associations were found in the proportion of DLRRC (all three species combined) by geographical region $\left(\chi^{2}=0.004\right.$, df 5 , NS) or agroecological zone $\left(\chi^{2}=\right.$ 0.036 , df 10 , NS). Despite no association with any particular region or zone, point pattern analysis of the spatial distributions of the three DLRRC species revealed highly significant spatial autocorrelation (clustering) patterns for each individual DLRRC species. Using Moran's I statistic, the $z$ scores and significance levels for the three DLRRC species were all highly significant $(F$. culmorum $z=-9.8, P<0.001$; $B$. sorokiniana $z=-8.6, P<0.001 ; F$. pseudograminearum $z=-3.1, P<0.001$ ). Hence, the spatial distribution of each DLRRC species exhibited a highly clustered, nonrandom pattern.

Investigation of environmental variables at survey locations (Table 1) revealed indications of potential niche separation between DLRRC species. As an example, data from the most common species, $F$. culmorum, provides an illustrative example, as year 2000 sites were significantly lower elevation $(t=6.16$, df $64, P<0.001)$ and higher annual precipitation $(t=7.1$, df $57, P<0.001)$ than year 2001 sites. However, due to the presence-or-absence nature of the survey results and the extensive multi-environment nature of the surveys, it was decided to combine both survey years for analytical purposes. This decision was further justified as analysis of 2001 data revealed the same significant trends as the combined year data results reported here.

Analysis of elevation values extracted from survey locations revealed significant differences between DLRRC species (ANOVA, $F_{2,129}=6.61, P \leq 0.002$ ), with $B$. sorokiniana occurring at significantly higher elevations than either $F$. culmorum $(t=2.9$, df $116, P<0.005)$ or $F$. pseudograminearum ( $t=3.2$, df $62, P \leq 0.002)$. No significant difference in elevation was observed between $F$. culmorum and $F$. pseudograminearum ( $t=1.36$, df 77, $P<$ 0.09, NS).

Annual precipitation, based on extracted historical long-term averages, was not significantly associated with differences of any DLRRC species (ANOVA, $F_{2,129}=$ $0.84, P<0.43$, NS). However, investigation of long-term normal precipitation data for specific 3-month periods revealed that F. pseudograminearum occurred in significantly higher long-term normal precipitation sites when considering the driest quarter (3 consecutive driest months) than either $F$. culmorum $(t=2.2$, df $11, P<$ $0.05)$ or B. sorokiniana ( $t=2.4$, df $11, P<$ $0.04)$. F. pseudograminearum also occurred in significantly wetter environments than $B$. sorokiniana in the warmest quarter $(t=21.6$, df $11, P<0.05)$.

The incidence of DLRRC species, calculated as the percentage of fields $(n)$ in each region with one or more of the DLRRC species present, was highest in the South East Anatolia region $(40 \%, n=60)$, followed by the Aegean (34\%, $n=137$ ), Mediterranean $(24 \%, n=17)$, Central Anatolian Plateau $(21 \%, n=200)$, Marmara $(20 \%, n=80)$, and Black Sea $(8 \%, n=24)$ regions (Table 2). Using the same metric for the agroecological zones, the winter wheat zone 1 covering the far eastern part of Turkey had the highest incidence of DLRRC (45\%).

Table 2. Incidence on a field basis of species of the dryland root rot complex ${ }^{\mathrm{a}}$ from wheat roots and crowns by agroecological zone and geographical region in 2001 and 2002

\begin{tabular}{|c|c|c|c|c|c|c|c|c|c|}
\hline \multirow[b]{2}{*}{ Agroecological zone $^{b}$} & \multirow[b]{2}{*}{ No. of fields } & \multicolumn{4}{|c|}{ Number of fields with species present } & \multicolumn{4}{|c|}{ Incidence $(\%)$} \\
\hline & & $F c$ & $F p$ & Bs & Total DLRRC & $F c$ & $F p$ & $B s$ & Total DLRRC \\
\hline 1 & 11 & 1 & 0 & 4 & 5 & 9 & 0 & 36 & 45 \\
\hline $3 \mathrm{~A}$ & 185 & 26 & 1 & 12 & 39 & 14 & 1 & 6 & 21 \\
\hline $4 \mathrm{~A} 1$ & 35 & 6 & 2 & 0 & 8 & 17 & 6 & 0 & 23 \\
\hline $4 \mathrm{~A} 2$ & 49 & 0 & 0 & 15 & 15 & 0 & 0 & 31 & 31 \\
\hline $4 \mathrm{~B}$ & 16 & 4 & 1 & 0 & 5 & 25 & 6 & 0 & 31 \\
\hline $5 \mathrm{~A} 1$ & 22 & 2 & 0 & 0 & 2 & 9 & 0 & 0 & 9 \\
\hline $5 \mathrm{~A} 2$ & 41 & 3 & 4 & 1 & 8 & 7 & 10 & 2 & 20 \\
\hline $5 \mathrm{~B}$ & 52 & 7 & 2 & 13 & 22 & 13 & 4 & 25 & 42 \\
\hline $5 \mathrm{C}$ & 33 & 7 & 1 & 6 & 14 & 21 & 3 & 18 & 42 \\
\hline 6 & 57 & 10 & 0 & 2 & 12 & 18 & 0 & 4 & 21 \\
\hline 7 & 17 & 4 & 0 & 0 & 4 & 24 & 0 & 0 & 24 \\
\hline \multicolumn{10}{|l|}{ Geographical region $^{c}$} \\
\hline Cent. Anatolian Plateau & 200 & 27 & 1 & 13 & 41 & 14 & 1 & 7 & 21 \\
\hline Aegean & 137 & 17 & 2 & 28 & 47 & 12 & 1 & 20 & 34 \\
\hline Marmara & 80 & 8 & 6 & 2 & 16 & 10 & 8 & 3 & 20 \\
\hline Mediterranean & 17 & 4 & 0 & 0 & 4 & 24 & 0 & 0 & 24 \\
\hline South East Anatolia & 60 & 12 & 2 & 10 & 24 & 20 & 3 & 17 & 40 \\
\hline Black Sea & 24 & 2 & 0 & 0 & 2 & 8 & 0 & 0 & 8 \\
\hline Total & 518 & 70 & 11 & 53 & 134 & & & & \\
\hline Incidence (\%) & & 14 & 2 & 10 & 26 & & & & \\
\hline
\end{tabular}

${ }^{a}$ Agroecological zone after Guler et al. (27) given in Figure 1.

${ }^{\mathrm{b}}$ Dryland root rot complex (DLRRC), which includes the species Fusarium culmorum $(F c)$, F. pseudograminearum (Fp), and Bipolaris sorokiniana (Bs).

${ }^{\mathrm{c}}$ Geographical regions as illustrated in Figure 1. 
The most commonly isolated DLRRC pathogen was F. culmorum, found in $14 \%$ of all fields. The highest frequency of isolation, relative to the total number of fields per region $(n)$, was from the Mediterranean region $(24 \%, n=17)$. Lower incidence occurred in South East Anatolia $(20 \%, n=$ 60), Central Anatolian Plateau (14\%, $n=$ 200), Aegean (12\%, $n=137)$, Marmara $(10 \%, n=80)$, and Black Sea $(8 \%, n=24)$ regions. This fungus was most frequently isolated from the facultative and spring eco-regions $4 \mathrm{~B}, 5 \mathrm{C}$, and 7 , which represent the South Eastern Anatolia and Mediterranean regions and the winter wheat ecoregion $3 \mathrm{~A}$ on the Central Anatolian Plateau (Table 1 and Fig. 1).

B. sorokiniana was the second most commonly isolated DLRRC pathogen (10\% of all fields). The frequency of isolation, relative to the total number of fields per region, was highest in the Aegean (20\%) and lower in South East Anatolia (17\%), Central Anatolian Plateau (7\%), and Marmara (3\%) regions. Unlike F. culmorum, B. sorokiniana tended to be associated more with the winter/facultative wheat environments, with $65 \%$ of its isolates found in agroecological zones 1 and 4A2. Compared to other species in the DLRRC, B. sorokiniana appeared to occur in the highest elevation environments.

The least commonly isolated of all DLRRC pathogens was $F$. pseudograminearum, found in only $2 \%$ of crown and root samples. The highest incidence of this fungus was in Marmara and South East Anatolia, representing predominately the spring wheat area of agroecological zone 5A2 (Table 1). Compared to other species in the DLRRC, F. pseudograminearum appeared to occur in the lowest elevations and correspondingly wetter environments.

Often the various DLRRC pathogens occurred individually in a particular field site; however, in many cases it was common to isolate two or more species from the group of stems. This was particularly the case for B. sorokiniana and Rhizoctonia spp. in the Aegean region and F. culmorum and Rhizoctonia spp. on the Central Anatolian Plateau, South East Anatolia, and the Aegean.

HRRRC. The incidence of isolation of G. graminis var. tritici and various species of Pythium was low (2\% of fields for $G$. graminis var. tritici and 3\% of fields for Pythium spp.). Unlike the DLRRC species, distribution patterns of $G$. graminis and Pythium spp. revealed no significant spatial autocorrelations or clustering (Morans I $z=0.5, P<0.35$ for $G$. graminis var. tritici, $z=-0.2, P<0.4$ for Pythium spp., both NS); hence distributions were considered to be random for both species. Analysis of environmental variables from sites of occurrence revealed no significant differences between the two species for any of the variables analyzed (i.e., elevation, an- nual precipitation, or precipitation during different quarters of the year).

Of the 12 fields with $G$. graminis var. tritici, six were from the Black Sea region, four were from by the Central Anatolian Plateau, and two were from Marmara. Considering the 15 Pythium spp. identified in the survey, the South East Anatolia region had the most positive fields (6), followed by the Central Anatolian Plateau (3), Black Sea (4), and Marmara (2).

Analysis of environmental factors comparing combined HRRRC data versus combined DLRRC revealed no significant differences in elevation, annual precipitation, or precipitation in the driest and warmest quarters (approximately summer period in Turkey) between the two groups.

Other species of cereal crown and root rotting fungi. More than 20 species of Fusarium were isolated from cereal roots and crowns of wheat (Table 3 ). Sixty percent of fields contained species of Fusarium other than $F$. culmorum and $F$. pseudograminearum. The most commonly isolated species were $F$. oxysporum and $F$. chlamydosporum (each from $11 \%$ of fields) and $F$. sporotrichioides (10\% of fields), followed by $F$. solani and $F$. acuminatum (8\%). F. solani was isolated most frequently in Aegean (16\%), Central Anatolian Plateau (11\%), and Marmara (7\%) regions. F. acuminatum was most common in Marmara (15\%), Aegean, and Central Anatolian Plateau (12\%). F. avenaceum

Table 3. Incidence on a field basis of isolating Fusarium spp. in 2001 and 2002 (excluding F. culmorum and F. pseudograminearum) from wheat roots and crowns by agroecological zone and geographical region

\begin{tabular}{|c|c|c|c|c|c|c|c|c|c|c|c|c|c|c|c|c|c|c|c|c|c|c|}
\hline \multirow{2}{*}{$\begin{array}{l}\text { Agroecological } \\
\text { zone }^{\text {b }}\end{array}$} & \multirow{2}{*}{$\begin{array}{l}\text { Total } \\
\text { fields }\end{array}$} & \multicolumn{21}{|c|}{ Number of fields with specific Fusarium species ${ }^{a}$} \\
\hline & & $a$ & av & ch & co & $d e$ & $e q$ & $f l$ & he & in & ja & la & $o x$ & po & $p r$ & se & so & sp & $t r$ & ve & spp & $\%^{\mathrm{c}}$ \\
\hline 1 & 11 & 0 & 3 & 0 & 0 & 0 & 0 & 0 & 0 & 0 & 0 & 0 & 1 & 0 & 0 & 0 & 2 & 0 & 0 & 0 & 0 & 54 \\
\hline $3 \mathrm{~A}$ & 166 & 12 & 6 & 5 & 2 & 0 & 4 & 1 & 3 & 3 & 3 & 1 & 5 & 0 & 0 & 5 & 11 & 5 & 1 & 8 & 2 & 45 \\
\hline 4A1 & 42 & 5 & 3 & 2 & 0 & 2 & 1 & 0 & 2 & 0 & 0 & 1 & 2 & 0 & 0 & 0 & 0 & 3 & 0 & 1 & 2 & 57 \\
\hline $4 \mathrm{~A} 2$ & 103 & 16 & 11 & 22 & 4 & 0 & 3 & 3 & 4 & 5 & 0 & 0 & 22 & 0 & 8 & 0 & 8 & 30 & 0 & 0 & 1 & 85 \\
\hline 4B & 13 & 1 & 0 & 2 & 0 & 0 & 0 & 0 & 0 & 0 & 0 & 0 & 0 & 0 & 0 & 0 & 0 & 1 & 0 & 0 & 0 & 31 \\
\hline $5 \mathrm{~A} 1$ & 23 & 3 & 5 & 0 & 1 & 0 & 0 & 0 & 1 & 0 & 1 & 0 & 0 & 1 & 1 & 0 & 1 & 0 & 0 & 0 & 2 & 70 \\
\hline $5 \mathrm{~A} 2$ & 37 & 2 & 2 & 1 & 1 & 1 & 0 & 0 & 2 & 0 & 0 & 0 & 3 & 0 & 0 & 0 & 6 & 1 & 1 & 1 & 1 & 57 \\
\hline $5 \mathrm{C}$ & 37 & 0 & 1 & 4 & 0 & 0 & 0 & 0 & 2 & 0 & 0 & 0 & 1 & 0 & 0 & 0 & 4 & 5 & 0 & 0 & 0 & 46 \\
\hline 6 & 69 & 4 & 1 & 19 & 0 & 0 & 3 & 3 & 16 & 0 & 0 & 0 & 18 & 2 & 6 & 0 & 9 & 8 & 0 & 0 & 0 & 72 \\
\hline 7 & 17 & 1 & 0 & 1 & 0 & 0 & 0 & 0 & 0 & 0 & 0 & 0 & 4 & 0 & 0 & 0 & 3 & 1 & 0 & 1 & 0 & 65 \\
\hline Total & 518 & 44 & 32 & 56 & 8 & 3 & 11 & 7 & 30 & 8 & 4 & 2 & 56 & 3 & 15 & 5 & 44 & 54 & 2 & 11 & 8 & \\
\hline \multicolumn{23}{|c|}{ Geographical region ${ }^{\mathrm{d}}$} \\
\hline $\begin{array}{l}\text { Cent. Anatolian } \\
\text { Plateau }\end{array}$ & 166 & 12 & 6 & 5 & 2 & 0 & 4 & 1 & 3 & 3 & 3 & 1 & 5 & 0 & 0 & 5 & 11 & 5 & 1 & 8 & 2 & 46 \\
\hline Aegean & 137 & 12 & 3 & 40 & 1 & 0 & 5 & 6 & 19 & 5 & 0 & 0 & 39 & 2 & 14 & 0 & 16 & 38 & 0 & 0 & 0 & 81 \\
\hline Marmara & 114 & 15 & 14 & 4 & 4 & 3 & 2 & 0 & 5 & 0 & 0 & 1 & 6 & 0 & 0 & 0 & 7 & 4 & 1 & 2 & 4 & 61 \\
\hline Mediterranean & 17 & 1 & 0 & 1 & 0 & 0 & 0 & 0 & 0 & 0 & 0 & 0 & 4 & 0 & 0 & 0 & 3 & 1 & 0 & 1 & 0 & 65 \\
\hline $\begin{array}{l}\text { South East } \\
\text { Anatolia }\end{array}$ & 50 & 1 & 1 & 6 & 0 & 0 & 0 & 0 & 2 & 0 & 0 & 0 & 1 & 0 & 0 & 0 & 4 & 6 & 0 & 0 & 0 & 42 \\
\hline Black Sea & 34 & 3 & 8 & 0 & 1 & 0 & 0 & 0 & 1 & 0 & 1 & 0 & 1 & 1 & 1 & 0 & 3 & 0 & 0 & 0 & 2 & 65 \\
\hline Total & 518 & 44 & 32 & 56 & 8 & 3 & 11 & 7 & 30 & 8 & 4 & 2 & 56 & 3 & 15 & 5 & 44 & 54 & 2 & 11 & 8 & 311 \\
\hline $\begin{array}{l}\text { Incidence of } \\
\text { isolation }(\%)\end{array}$ & 8 & 6 & 11 & 2 & 1 & 2 & 1 & 6 & 2 & 1 & 0 & 11 & 1 & 3 & 1 & 8 & 10 & 0 & 2 & 2 & 60 & \\
\hline
\end{tabular}

${ }^{a} F$. acuminatum (a), F. avenaceum (av), F. chlamydosporum (ch), F. compactum (co), F. detonianum (de), F. equiseti (eq), F. lateritium (fl), F. heterosporum (he), F. inflexum (in), F. javanicum (ja), F. lateritium (la), F. oxysporum (ox), F. poae (po), F. proliferatum (pr), F. semitectum (se), F. solani (so), F. sporotrichioides ( $s p$ ), F. tricinctum (tr), F. verticillioides (ve), other Fusarium species unidentified (spp).

${ }^{\mathrm{b}}$ Agroecological zone after Guler et al. (27) given in Figure 1.

c \% samples with Fusarium species (excluding F. culmorum and F. pseudograminearum).

${ }^{\mathrm{d}}$ Geographical regions in Turkey as illustrated in Figure 1. 
and $F$. heterosporum were found in $6 \%$ of all fields, and all other species were found in frequencies less than $3 \%$.

The Aegean region had the highest percentage of fields with Fusarium spp. $(81 \%)$. Lower percentages occurred in the Mediterranean and Black Sea (each with 65\%), Marmara (61\%), Central Anatolian Plateau (46\%), and South East Anatolia (42\%) regions. The highest Fusarium diversity in a given sample (data not shown) occurred in agroecological zone 4A2, including much of the transitional zone of the Central Anatolian Plateau, Aegean, and parts of Marmara and zone 6, representing predominately the Aegean. At least one species of Fusarium was found in 85 and $72 \%$ of samples from zones $4 \mathrm{~A} 2$ and 6 , respectively, and 34 and $40 \%$ of samples, respectively, had two or more species.

Cereal pathogens other than Fusarium and B. sorokiniana are shown in Table 4 and include Microdochium nivale, Phoma spp., Pseudocercosporella herpotrichoides, Rhizoctonia solani, and other Rhizoctonia spp. Most striking is the high incidence of Rhizoctonia spp., with $22 \%$ of the fields harboring species other than $R$. solani, which was detected at a low incidence of $2 \%$. Rhizoctonia spp. were highly prevalent in this study, with the majority of isolates from the Aegean (39\%), Marmara (37\%), and Central Anatolian Plateau (31\%) regions. This field site incidence was higher than that of the two most commonly documented root rot pathogens $F$. culmorum and $B$. sorokiniana for the Aegean (17 and 28\%), Marmara (8 and 2\%), and Central Anatolian Plateau (27 and 13\%). The main Rhizoctonia species ap- peared to be $R$. cerealis; however, further confirmation studies are necessary. As with Fusarium spp. other than F. culmorum and $F$. pseudograminearum, the highest incidence was found again in agroecological zones 4A2 and 6, representing Marmara, Aegean, and Central Anatolian Plateau regions.

Microdochium nivale was found at a low incidence of 3\% from the Marmara, Central Anatolian Plateau, and South East Anatolian regions. Phoma spp. was found in $11 \%$ of all fields, most commonly from the Aegean region and to a limited extent the Central Anatolian Plateau. P. herpotrichoides was found at a low incidence of $1 \%$ and only from Marmara, which could be expected for a basal stem pathogen that is unlikely to be detected by isolations from root and crown tissues performed in this survey.

\section{DISCUSSION}

This is the first report of a nationwide survey of wheat crown and root rots in Turkey. The findings presented here are in general agreement with other regional studies conducted across cereal growing regions of Turkey $(3,4,33)$, each of which reported that F. culmorum, B. sorokiniana, and Rhizoctonia spp. were the most common causal agents of dryland root rot on wheat. Bentley et al. (8) isolated 16 Fusarium species from wheat stem bases across 25 sites in parts of the Aegean, Marmara, and Black Sea regions, with F. oxysporum, F. equiseti, $F$. acuminatum, $F$. sambucinum, $F$. culmorum, and $F$. armeniacum being the most frequent. $F$. solani, $F$. pseudograminearum, and other species were found at low frequencies. The largest numbers of Fusarium species in Bentley's study (8) were isolated from the Marmara coastal region. In contrast, comparing the same three regions in this study, the Aegean had both a higher diversity and frequency of Fusarium spp. The low frequency of isolation of $F$. pseudograminearum was observed in both surveys. As with this report, Demirci and Dane's (22) study in the eastern part of the Anatolia region indicated isolation of both $F$. acuminatum and $F$. oxysporum. However, they did not report $F$. avenaceum, unlike our study, and we did not detect $F$. equiseti and $M$. nivale, as was indicated in their study. These differences in part may be explained due to different sampling and isolation methods or possibly the more limited number of samples taken in these smaller regional surveys.

It is accepted that F. culmorum, F. pseudograminearum, and $B$. sorokiniana are pathogenic on wheat plants $(12,41,46)$. Aktaş (2) reported that $B$. sorokiniana is the major pathogen causing severe root rot disease and important yield losses of barley in the Central Anatolia region. F. pseudograminearum was the dominant Fusarium species causing crown and root rot in the eastern wheat belt of Australia $(11,15)$; however, other Fusarium spp. were important pathogens in specific eco-climatic regions. For example, F. culmorum accounted for more than $70 \%$ of the isolates obtained from the high rainfall and colder cereal region of Victoria and southeast South Australia (52). Other Fusarium spp., including $F$. acuminatum, $F$. avenaceum, $F$. culmorum, F. crookwellense, and F. equi-

Table 4. Incidence on a field basis of other fungi (excluding Fusarium spp. and Bipolaris sorokiniana) isolated from wheat roots and crowns by agroecological zone and geographical region in 2001 and 2002

\begin{tabular}{|c|c|c|c|c|c|c|c|c|}
\hline \multirow[b]{2}{*}{ Agroecological zone $^{b}$} & \multirow[b]{2}{*}{ No. of fields } & \multicolumn{7}{|c|}{ Number of fields with particular species ${ }^{\mathrm{a}}$} \\
\hline & & Ggt & $M n$ & $P h$ & $P s$ & $P y$ & $R s$ & $R$. spp \\
\hline 1 & 11 & 0 & 0 & 0 & 0 & 0 & 0 & 0 \\
\hline $3 \mathrm{~A}$ & 166 & 6 & 6 & 5 & 0 & 7 & 0 & 25 \\
\hline $4 \mathrm{~A} 1$ & 42 & 1 & 7 & 0 & 0 & 0 & 0 & 3 \\
\hline $4 \mathrm{~A} 2$ & 103 & 1 & 0 & 32 & 2 & 3 & 5 & 28 \\
\hline $4 \mathrm{~B}$ & 13 & 1 & 1 & 0 & 0 & 2 & 0 & 2 \\
\hline $5 \mathrm{~A} 1$ & 23 & 2 & 0 & 1 & 0 & 1 & 0 & 1 \\
\hline $5 \mathrm{~A} 2$ & 37 & 0 & 2 & 1 & 1 & 0 & 1 & 2 \\
\hline $5 \mathrm{C}$ & 37 & 0 & 1 & 1 & 0 & 1 & 0 & 1 \\
\hline 6 & 69 & 0 & 0 & 17 & 0 & 0 & 5 & 28 \\
\hline 7 & 17 & 0 & 0 & 0 & 0 & 1 & 0 & 1 \\
\hline Total & 518 & 11 & 17 & 57 & 3 & 15 & 11 & 91 \\
\hline \multicolumn{9}{|l|}{ Geographical region ${ }^{\mathrm{c}}$} \\
\hline Cent. Anatolian Plateau & 166 & 6 & 6 & 5 & 0 & 7 & 0 & 31 \\
\hline Aegean & 137 & 0 & 0 & 49 & 0 & 1 & 9 & 39 \\
\hline Marmara & 114 & 2 & 9 & 1 & 3 & 2 & 2 & 37 \\
\hline Mediterranean & 17 & 0 & 0 & 0 & 0 & 1 & 0 & 1 \\
\hline South East Anatolia & 50 & 1 & 2 & 1 & 0 & 3 & 0 & 3 \\
\hline Black Sea & 34 & 2 & 0 & 1 & 0 & 1 & 0 & 1 \\
\hline Total & 518 & 11 & 17 & 57 & 3 & 15 & 11 & 91 \\
\hline Incidence of isolation (\%) & & 2 & 3 & 11 & 1 & 3 & 2 & 22 \\
\hline
\end{tabular}

${ }^{a}$ Gaeumannomyces graminis var. tritici (Ggt), Microdochium nivale (Mn), Phoma spp. (Ph), Pseudocercosporella herpotrichoides (Ps), Pythium spp. (Py),

Rhizoctonia solani (Rs), other Rhizoctonia spp. (R. spp).

${ }^{\mathrm{b}}$ Agroecological zone after Guler et al. (27) given in Figure 1.

${ }^{\mathrm{c}}$ Geographical region as illustrated in Figure 1. 
seti, are also regularly isolated from crown and stem tissue of wheat in eastern Australia but are regarded as saprophytes acting as secondary colonizers rather than pathogens $(11,15)$. Smiley and Patterson (47) reported isolates of F. culmorum, F. pseudograminearum, and $B$. sorokiniana as being highly pathogenic to winter wheat, causing damping-off and/or rotting of stem bases leading to seedling death. Isolates of $F$. avenaceum and $M$. nivale were also considered pathogenic. Similarly in Australia, 10 Fusarium species ( $F$. acuminatum, $F$. avenaceum, $F$. baninda, $F$. graminearum, $F$. crookwellense, $F$. proliferatum, F. pseudograminearum, F. subglutinans, $F$. torulosum, and $F$. tricinctum) isolated from the crown and spike of wheat were found capable of producing crown rot under laboratory conditions (1). In Canada, Fernandez and Chen (25) also found that $F$. culmorum caused greater discoloration of the subcrown internodes and affected plant emergence to a greater extent than $F$. graminearum, $F$. avenaceum, $F$. equiseti, or F. poae. It is plausible to expect that these species could also be pathogenic under conditions in Turkey, and several pathogenicity studies have been reported. Aktaş et al. (5) revealed that $F$. verticillioides was one of the most virulent pathogens on crowns of wheat and that $B$. sorokiniana, $G$. graminis var. tritici, and $F$. culmorum also had highly pathogenic reactions, while $P$. graminicola had moderate pathogenicity on winter wheat variety Katea A-1 under greenhouse conditions. Recent work by Tunali et al. (48) has clearly demonstrated under greenhouse conditions that a range of F. culmorum, F. pseudograminearum, and $F$. graminearum isolates are all highly pathogenic on crowns of winter wheat Pehlivan, whereas other species such as $F$. subglutinans, F. oxysporum, F. acuminatum, $F$. solani, and $F$. verticillioides were weak pathogens. This agrees with Aktaş (5) with the exception of $F$. verticillioides. Demirci and Dane (22) examined the cause of crown and root rots on winter wheat Kirik under greenhouse conditions and found that $M$. nivale was the most virulent pathogen, while $F$. acuminatum, $F$. equiseti, $F$. oxysporum, and $F$. solani were slightly virulent. Under field conditions, the dominant species in the DLRRC varied in individual fields from year to year and among regions in the U.S. Pacific Northwest, indicating a high level of adaptation as members of the pathogen complex respond to changes in temperature, seasonal distribution, and amount of moisture, and other edaphic factors.

GIS tools utilized in this study revealed that the three species of the DLRRC ( $F$. culmorum, $F$. pseudograminearum, and $B$. sorokiniana) exhibited a highly significant nonrandom, clustered spatial distribution of occurrence. There was no significant association with any particular region or agroecological zone for any species. There were strong indications of niche separation with $B$. sorokiniana occurring at higher elevations and $F$. pseudograminearum occurring at lower elevations and wetter winter environments. As previously reported by several authors, the effects of dryland root rot involving $F$. pseudograminearum, F. culmorum, and B. sorokiniana were more pronounced under stress conditions during the growing season as is commonly experienced under limited rained conditions found in Australia, the U.S. Pacific Northwest, and Canada $(6,7,35,41,42,45)$. This also has important implications in Turkey, as much of the 5 Mha of winter wheat grown on the Central Anatolia plateau located at average elevation of $900 \mathrm{~m}$ in the inner part of Turkey (mostly zone $3 \mathrm{~A}$, part $2 \mathrm{~B}, 3 \mathrm{~B}$, and 4A2; Fig. 1) is under rained conditions associated with drought stress at the end of the season. Supplementary irrigation is available only in limited cases. In this survey, only key macro-environment variables such as rainfall and elevation were analyzed and not micro-variables such as soil type and moisture. If these were available, they might have explained some of the cluster distributions for specific species.

The 2-year extensive study conducted by Smiley and Patterson (47) with 288 fields in the Pacific Northwest also revealed similar isolation frequencies of the major causal agents of root rots. However in their case, F. pseudograminearum was more common, with field isolation frequencies of 27 and $16 \%$ in years 1 and 2 compared to 14 and $7 \%$ for $F$. culmorum. In our study, F. culmorum was more common (14\%) than $F$. pseudograminearum (2\%). Similar findings were also made by the limited survey in the Black Sea and Aegean regions by Bentley et al. (8). The reasons for these differences are not clear given that the environmental conditions in both the Pacific Northwest and Turkey are somewhat comparable in the winter wheat growing areas. Considering Turkey is one of the regions associated with the evolution of wheat, it may also be a center of diversity for F. culmorum. Another possibility is differences in crop rotational patterns and the differential hosting abilities for Fusarium species, although much of the Pacific Northwest is similarly a wheat-fallow cropping system.

One of the major findings in this study was the high field incidence (22\%) of Rhizoctonia spp., which were mostly species other than $R$. solani (2\%). It was likely that the majority of the Rhizoctonia isolates were $R$. cerealis, which differs from $R$. solani by having binucleate hyphal cells and a relatively slow growth rate (32). These species are similar in other morphological features, making species identification in this type of study difficult. The importance of $R$. cerealis in Turkey has been highlighted in several publications
$(4,5)$, and it has also been reported to be widespread and an economically important crown pathogen of winter wheat in both China and New Zealand (20,27,31). This fungus is also reported from several other temperate countries including the Netherlands, Germany, South Africa, and the United Kingdom (15,32). Sowing date, soil moisture and temperature can affect sharpeye spot severity (51), with disease incidence usually greatest in early autumnsown crops (21). Mathre (34) also reported that acid, sandy, and dry (less than $20 \%$ moisture holding capacity) soils increased disease risk of $R$. cerealis, as did cool spring temperatures. This is likely an important crown pathogen in Turkey and warrants further investigation.

The isolation of the HRRRC root and crown fungi was very low, which is expected given Turkey's cereal production environment. The various species associated with the HRRRC were found in both the high and low rainfall sites. The highest frequency of isolation of these fungi in the Black Sea region represents the highest rainfall in Turkey (agroecological zone 5A1, $600 \mathrm{~mm}$ ).

In this survey, the cereal growing regions of South East Anatolia, Central Anatolian Plateau, Marmara, and Black Sea regions had the highest frequency of isolation of DLRRC species, including Rhizoctonia spp. More than two-thirds of Turkey's 10 Mha of wheat is in this area, with $60 \%$ being rained or under suboptimal irrigation that would allow late season plant stress in most years. Hekimhan et al. (29) demonstrated that the root rot complex (F. culmorum, F. pseudograminearum, and B. sorokiniana) caused $24 \%$ yield loss in common bread wheats with two supplementary irrigations over a 3-year study on the Central Anatolian Plateau in Konya province. On this basis, if $60 \%$ of this 6.77 Mha of both winter and spring wheat is grown under suboptimal moisture conditions (rained with or without suboptimal irrigation), and this region suffered an average conservative estimate of $10 \%$ yield loss due to dryland root rots per year, the total loss to production would be $1.33 \mathrm{Mt}$ per year or approximately $7 \%$ of the annual production of approximately $20 \mathrm{Mt}$. This loss is significant and warrants active wheat screening and breeding programs for dryland root rot resistance and tolerance. These improvement programs have been actively initiated in joint Turkey and International (CIMMYT) efforts $(37,38)$.

\section{ACKNOWLEDGMENTS}

This research was supported by funds of General Directorate of Agricultural Research. We also appreciate colleagues who assisted in collecting samples from their regions representing the Agricultural Research Institutes of Sakarya, Eskişehir, Samsun, Edirne, Malatya, Şanlıurfa, and Plant Protection Institute of Diyarbakır. Thanks are also given to Etienne Duveiller and Myriam Fernandez for their constructive advice during preparation of the manuscript. 
LITERATURE CITED

1. Akinsanmi, O. A., Miller, V., Simptendorfer, S., Backhouse, D., and Chakraborty, S. 2004. Identity and pathogenicity of Fusarium spp. isolated from wheat fields in Queensland and northern New South Wales. Aust. J. Agric. Res. 55:97-107.

2. Aktaş, H. 1982. Spreading of root rot pathogen (Drechslera sorokiniana (Sacc.) Subram. and Jain.) on barley and wheat growing areas in Central Anatolia Region. Pages 10-23 in: III. Türkiye Phytopatology Congress Book, Adana.

3. Aktaş, A., Bolat, N., Keser, M., and Ince, T. 2000. Determination of the cereal root and crown rot disease agents in the Eskișehir cereal growing areas and researches on the genitor varieties and lines against Drechslera sorokiniana (Sacc) Subram. and Jain. in wheat and barley. Plant Prot. Bull. 40:71-83.

4. Aktaș, H., Bostancioğlu, H., Tunalı, B., and Bayram, E. 1996. Determination of the root rots agents and their interference with cultural practices in Sakarya Region. Plant Prot. Bull. 36:151-167.

5. Aktaş, H., Bostancioğlu, H., Tunalı, B., and Bayram, E. 1997. Reactions of some wheat varieties and lines against to root and foot rot disease agents in field and laboratory conditions. J. Turkish Phytopathol. 26:61-68.

6. Bailey, K. L., Harding, H., and Knott, D. R. 1989. Disease progression in wheat lines and cultivars differing in levels of resistance to common root rot. Can. Plant Pathol. 11:273278.

7. Barnett, H. L., and Hunter, B. B. 1998. Illustrated Genera of Imperfect Fungi. American Phytopathological Society. St. Paul, MN.

8. Bentley, A. R., Tunali, B., Nicol, J., Burgess, L. W., and Summerell, B. A. 2006. A survey of Fusarium species associated with wheat stem bases in northern Turkey. Sydowia 58:163-177.

9. Booth, C. 1977. Fusarium Laboratory Guide to the Identification of Major Species. Commonw. Mycol. Inst., Kew, Surrey, England.

10. Braun, H. J., Zencirci, N., Altay, F., Atli, A., Avci, M., Eser, V., Kambertay, M., and Payne, T. S. 2001. Turkish wheat pool. Pages 851-879 in: World Wheat Book - A History of Wheat Breeding. A. P. Bonjean and W. P. Angus, eds. Lavoisier Publishing, Paris, France.

11. Burgess, L. W. 1981. General ecology of the Fusaria. Pages 225-235 in: Fusarium: Diseases, Biology and Taxonomy, P. E. Nelson, J. A. Toussoun, and R. J. Cook, eds. Pennsylvania State University, University Park.

12. Burgess, L. W., Backhouse, D., Summerell, B. A., and Swan, L. J. 2001. Crown rot of wheat. Pages 271-295 in: Fusarium - Paul E. Nelson Memorial Symposium. B. A. Summerell, J. F. Leslie, D. Backhouse, W. L. Bryden, and L. W. Burgess, eds. American Phytopathological Society, St. Paul MN.

13. Burgess, L. W., Summerell, B. A., Bullock, S., Gott, K., and Backhouse, D. 1994. Laboratory Manual for Fusarium Research. 3rd ed. Fusarium Research Laboratory, University of Sydney, Sydney, Australia.

14. Chakraborty, S., Liu, C. J., Mitter, V., Scott, J. B., Akinsanmi, O. A., Ali, S., Dill-Macky, R., Nicol, J., Backhouse, D., and Simpfendorfer, S. 2006. Pathogen population structure and epidemiology are keys to wheat crown rot and Fusarium head blight management. Aust. Plant Pathol. 35:643-655.

15. Clarkson, J. D. S., and Cook, R. J. 1983. Effect of sharp eyespot on yield loss in winter wheat. Plant Pathol. 32:421-428.

16. Cook, R. J. 1981. Fusarium diseases of wheat and other small grain in North America. Pages 39-52 in: Fusarium: Diseases, Biology and Taxonomy. P. E. Nelson, T. A. Toussoun, and R. J. Cook, eds. Pennsylvania State University, University Park.

17. Cook, R. J., Sitton, J. W., and Haglund, W. A.
1987. Influence of soil treatments on growth and yield of wheat and implications for control of Pythium root rot. Phytopathology 77:11921198.

18. Cook, R. J., Sitton, J. W., and Waldher, J. T. 1980. Evidence of Pythium as a pathogen of direct-drilled wheat in the Pasific Northwest. Plant Dis. 64:102-103.

19. Cook, R. J., and Veseth, R. J. 1991. Wheat Health Management. American Phytopathological Society, St. Paul, MN.

20. Cromey, M. G., Butler, R. C., Boddington, H. J., and Moorhead, A. R. 2002. Effects of sharp eyespot on yield of wheat (Triticum aestivum). N.Z. Crop Hortic. Sci. 30:9-17.

21. Cromey, M. G., Butler, R. C., Munro, C. A., and Shorter, S. C. 2005. Susceptibility of the New Zealand wheat cultivars to sharp eyespot. N.Z. Plant Prot. 58:268-272.

22. Demirci, E., and Dane, E. 2003. Identification and pathogencity of Fusarium spp. from stem bases of winter wheat in Erzurum, Turkey. Phytoparasitica 31:170-173.

23. Domsch, K. H., Gams, W., and Anderson, T.H. 1980. Compendium of Soil Fungi. Academic Press, London.

24. Ellis, M. B. 1976. More Dematiaceous Hyphomycetes. Commonw. Mycol. Inst., Kew, Surrey, England.

25. Fernandez, M. R., and Chen, Y. 2005. Pathogenicity of Fusarium species on different plant parts of spring wheat under controlled conditions. Plant Dis. 89:164-169.

26. Gerlach, W., and Nirenberg, H. I. 1982. The Genus Fusarium: A Pictorial Atlas. Mitt. Biol. Bundesanst. Land-Forstwirtsch. Berlin, Dahlem.

27. Guler, M., Karaca, M., and Durutan, N. 1990. Agricultural Climatic Zones in Turkey. Central Research Inst. for Field Crops. TMO Printhouse, Ankara, Turkey.

28. He, W., Song, Y., and Zhang, Z. 1998. Evaluation of resistance of wheat cultivars to sharp eyespot. Genet. Resour. 39:30-31.

29. Hekimhan, H., Bağci, A., Nicol, J. M., Arisoy, Z., Taner, S., and Sahin, S. 2004. Dryland root rot: A major threat to winter cereal production under sub-optimal growing conditions. Page 283 in: 4th Int. Crop Sci. Congr. Brisbane, Australia.

30. Hijmans, R. J., Cameron, S. E., Parra, J. L., Jones, P. G., and Jarvis, A. 2005. Very high resolution interpolated climate surfaces for global land areas. Int. Climatol. 25:1965-1978.

31. Hongxia, Y., Honglian, L., and Shouzheng, W. 1998. Identification of resistance to wheat sharp eyespot in wheat relatives. Acta Agric. Boreali-Sinica. 13:26-29.

32. Lipps, P. E., and Herr, L. J. 1982. Etiology of Rhizoctonia cerealis in sharp eyespot of wheat. Phytopathology 72:1574-1577.

33. Mamluk, O. F., Cetin, L., Braun, H. J., Bolat, N., Bertschinger, L., Makkouk, K. M., Yıldrım, A. F., Saari, E. E., Zencirci, N., Albustan, S., Çall, S., Beniwal, S. S. P. S., and Düșünceli, F. 1997. Current status of wheat and barley diseases in the Central Anatolian Plateau of Turkey. Phytopathologia-Mediterranea. 36:167-181.

34. Mathre, D. E. 1985. Compendium of Barley Diseases. American Phytopathological Society, St Paul, MN.

35. Mergoum, M., Lyamani, A., and Nsarellah, N. 1995. Root rot of wheat. Al Awamia 89:1-24.

36. Mitra, M. 1930. A comparative study of species and strains of Helminthosporium on cereals in Indian cultivated crops. Trans. Br. Mycol. Soc. 15:254-293.

37. Nicol, J. M., Bagci, A., Hekimhan, H., Bolat, N., Braun, H. J., and Trethowan, R. 2004. Strategy for the identification and breeding of resistance to dryland root rot complex for international spring and winter wheat breeding programs. Page 283 in: Proc. 4th Int. Crop Sci. Congr., Brisbane, Australia.
38. Nicol, J. M., Rivoal, R., Trethowan, R. M., van Ginkel, M., Mergoum, M., and Singh, R. P. 2001. CIMMYT's approach to identify and use resistance to nematodes and soil-borne fungi in developing superior wheat germplasm. Pages 381-389 in: Wheat in a Global Environment. Z. Bedo and L. Lang, eds. Proc. 6th Int. Wheat Conf., Budapest, Hungary. Kluwer Academic Publishers, Netherlands.

39. Pankhurst, C. E., McDonald, H. J., and Hawke, B. G. 1985. Influence of tillage and crop rotation on the epidemiology of Pythium interactions of wheat in a red-brown earth of South Australia. Soil. Biol. Biochem. 27:1065-1073.

40. Papendick, R. I., and Cook, R. J. 1974. Plan water stress and development of Fusarium foot rot in wheat subjected to different cultural practices. Phytopathology 64:358-363.

41. Paulitz, T. C., Smiley, R. W., and Cook, R. J. 2002. Insights into the prevalence and management of soilborne cereal pathogens under direct seeding in the Pacific Northwest, USA Can. Plant Pathol. 24:416-428.

42. Piening, L. J., Atkinson, T. G., Horricks, J. S. Ledingham, R. J., Mills, J. T., and Tinline, R. D. 1976. Barley losses due to common root rot in the prairie provinces of Canada, 1970-1972. Can. Plant Dis. Surv. 56:41-45.

43. Saari, E. E. 1985. Distribution and importance of root rot diseases of wheat, barley and triticale in south and Southeast Asia. Pages 189. 195 in: Wheats for More Tropical Environments. CIMMYT, Mexico, DF.

44. Singh, K., Fricvad, J. C., Thrane, U., and Mathur, S. B. 1991. An Illustrated Manual on Identification of Some Seed-borne Aspergilli, Fusaria, Penicilia and their Mycotoxins. Danish Gov. Inst. Seed Pathology Developed Countries, Denmark.

45. Singh, R. P., Huerta-Espino, J., Fuentes, G., Duveiller, E., Gilchrist, L., Henry, M., and Nicol, J. M. 2005. Resistance to Diseases. Pages 291-327 in: Durum Wheat Breeding: Current Approaches and Future Strategies. C. Royo, M. Nachit, N., Di Fonzo, J. Araus, W. P. Pfeiffer, and G. Slafer, eds. Food Product Press, New York.

46. Smiley, R. W., Gourlie, J. A., and Easley, S. A. 2005. Pathogencity of fungi associated with the wheat crown rot complex in Oregon and Washington. Plant Dis. 89:949-957.

47. Smiley, R. W., and Patterson, L. M. 1996 Pathogenic fungi associated with Fusarium foot rot of winter wheat in the semiarid Pacific Northwest. Plant Dis. 80:944-949.

48. Tunali, B., Nicol, J. M., Erol, F. Y., and Alt1parmak, G. 2006. Pathogenicity of Turkish crown and head scab isolates on stem bases on winter wheat under greenhouse conditions. J. Plant Pathol. 5:143-149.

49. Upton, G. J., and Fingleton, B. 1985. Spatial Data Analysis by Example, Vol. 1: Point Pattern and Quantitative Data. Wiley Inc., Toronto.

50. Walker, J. 1981. Taxonomy of the take-all fungi and related genera and species. Pages 15 74 in: Biology and Control of Take-all. M. J. C. Asher and P. J. Shipton, eds. Academic Press, London, UK.

51. Weise, M. V. 1987. Compendium of Wheat Diseases, 2nd ed. American Phytopathological Society, St. Paul, MN

52. Williams, K. J., Dennis, J. I., Smyl, C., and Wallwork, H. 2002. The application of speciesspecific assays based on the polymerase chain reaction to analyses Fusarium crown rot of durum wheat. Aust. Plant Pathol. 31:119-129.

53. Zadoks, J. C., Chang, T. T., and Konzak, C. F. 1974. A decimal code for the growth stages of cereals. Weed Res. 14:415-421.

54. Zillinsky, F. J. 1983. Common Diseases of Small Grain Cereals: A Guide to Identification. The International Maize and Wheat Improvement Center (CIMMYT), Mexico, DF 